\title{
The spirit of the National Peace Accord: The past and future of conflict resolution in South Africa
}

\section{Deji Olukotun ${ }^{\star}$}

\begin{abstract}
This article seeks to examine the evolution of the conflict resolution community in South Africa through a combination of history and policy analysis. Each section roughly corresponds to the past and future of conflict resolution in the country. The connection between these sections is at times causal-in the sense that some events directly shaped the next - but more often thematic- meaning that certain trends may be traced throughout the evolution of the community. Consultation with more than ten conflict resolution organisations and interviews with over twenty leading practitioners offer valuable insights to the investigation.

The article begins with an analysis of the rise and fall of the National Peace Accord. The study demonstrates that government endorsement of the Accord did not detract from the ability of the peace committees to furnish the nation with a reservoir of practical conflict resolution skills. Communication, aided in part by the South African Council of Churches, helped avert violence and steer

* Deji Olukotun has obtained the following degrees: J.D. Stanford, M.Phil. and M.A. University of Cape Town, B.A. Yale; and is admitted to the California and New Jersey Bars. The author would like to thank Professor Wilfried Schärf at the University of Cape Town for his patience and counsel in the preparation of this article.
\end{abstract}




\section{Deji Olukotun}

the country clear of civil war. Peace work was more successful when national, regional, and local levels were coordinated. At the same time, the Accord's attempt to resolve greater structural inequalities in its peacebuilding initiatives fell short of its goals. The business community enjoyed managing the process, but offered little in terms of actual resources and training as it high-tailed it 'back to the balance sheets.'

The second section of the article analyses the work of the South African Law Commission's Project 94. This project would mark a shift to the spirit of the National Peace Accord by wedding local conflict resolution mechanisms to the state. The places to which people already go to resolve conflicts - the 'other law' - have been providing justice to South Africans for decades. But recognition of these ordering mechanisms is itself beset with difficulties. The 'other law' is pluralistic in nature, making it difficult to make naturally subversive and organic entities conform to the formal justice system. The state is under-resourced, but seems wary of granting too much power to unpredictable dispute resolution structures. Guidelines may provide some certainty, but this does not disguise the uncertainty of the political process itself - the Draft Bill may disappear once it enters the legislature. This political reality is compounded by the fact that the Draft Bill itself permits either the government or community dispute resolution structures to end their liaison at any time, undermining commitment. The creation of a new National Peace Accord therefore appears unlikely in the short term.

The hope is that the reader will leave with a better understanding of the conflict resolution community and of the complexity of issues facing South Africa today. If nothing else, South Africa's unbridled forays into conflict resolution will be revealed as undeniably inspiring.

\section{Introduction}

South Africa emerged from apartheid at the forefront of the conflict resolution community. The numerous social and political forces required to shepherd

1 Interview with Peter Gastrow. 
the transition to majority rule had trained people at every level of society. Domestically, labour experts, social activists, clerics, politicians, community leaders, and business gurus had lent their skills to the country. Internationally, practitioners from around the world had seized the opportunity to wed their cutting-edge theories to South Africa in a workable praxis. These efforts were complemented by underground networks of street committees and other popular forms of justice. Nonetheless, over 20000 people lost their lives between 1985 and 1994 alone. At no time was the seemingly intractable conflict guaranteed to enjoy a peaceful handover (Rothchild 1997:194). Civil war remained a viable prospect until election day on April 27, 1994, when disappointed journalists packed up their bags and headed to the genocide in Rwanda. ${ }^{2}$

The nation enjoyed a short honeymoon of constitution-making and democratic processes. South Africans adapted to democracy so thoroughly that they could design an inclusive problem-solving mechanism at an hour's notice, and became 'processed out of their skulls.' By 1999-2000, the country's conflict resolution community was at its apogee, possessing an unmatched reservoir of hands-on experience and home-grown theory. ${ }^{4}$ Today, the honeymoon has ended. Some government promises were kept, while others were not, and practitioners have been absorbed by politics, business, or scattered across the world in a new Diaspora. ${ }^{5}$ Fifteen years after the transition, over 90 percent of land remains in the hands of the white minority and new terrors such as HIV/AIDS have transformed the political landscape (Centre for Conflict Resolution 2004). The conflict resolution community has undergone profound changes in turn.

This article seeks to examine the evolution of the conflict resolution community in South Africa through a combination of history and policy analysis. The first section offers a study of the National Peace Accord, the national mechanism that helped pave the way for the multiparty negotiations and the interim government.

2 Interview with Roger Lucey, former SABC journalist (Jan. 2006).

3 Interview with Ghalib Galant, Facilitator, Synergy Works (24 Jan. 2006).

4 Interview with Sean Tait, Director: Criminal Justice Initiative, Open Society Foundation for South Africa (20 Sep. 2005).

5 Interview with Susan Collin Marks, Executive Vice-President, Search for Common Ground (22 Dec. 2005). 


\section{Deji Olukotun}

Emerging from a joint effort of the religious and business communities, the Accord's system of local, regional, and national Peace Committees furnished conflict resolution skills on an unprecedented level to the entire nation. The successful initiative was hastily dismantled by the interim and elected governments, but certain themes - the 'spirit' of the Accord - continue to shape contemporary South Africa.

The second section will examine the South African Law Commission's Project 94, which is currently assessing the possibility of wedding state institutions to non-state forms of conflict resolution. This section will briefly highlight the vibrant history of non-state justice actors in South Africa. It will then proceed to analyse the legal and political questions that arise in extending the reach of the state to areas in which it was heretofore absent. Questions of access to justice, jurisdiction, and service delivery will be discussed to determine whether a kind of 'New National Peace Accord' may be fashioned.

\section{Clipped wings: The rise and fall of the National Peace Accord}

A solitary gunman walked towards Chris Hani in front of his home in Boksburg, Johannesburg and fired four shots into his head, killing him instantly on 13 April 1993 (Mandela 1994:599). Hani, South African Communist Party president, guerrilla veteran, and leader of the African National Congress, had proven to be one of the lone voices capable of restraining an increasingly militant African youth. An informer revealed the assassin to be a white Polish immigrant and member of the right-wing Afrikaner Weerstandsbeweging 6 party, and the nation viewed the event as a deliberate move to destabilise the ongoing negotiation process. The youth bristled and clamoured for violence. In response, the ANC leadership organised a series of commemorative marches to prevent retaliatory attacks (Mandela 1994:600).

In Cape Town, a Church service predicted to attract 10000 people swelled to 50 000, and ANC peace marshals found themselves overwhelmed (Collin

6 Resistance Movement. 
Marks 2000:77). Unable to hear Archbishop Tutu and party leaders express their recognition of Hani, the marchers turned their eye towards the nervous, inexperienced police, as Collin Marks (2000:77) recalls:

Leaderless, frustrated, and spoiling for trouble, gangs of youths go on the rampage, stoning the stalls and nearby shops, breaking windows in preparation for looting, and setting fire to parked vehicles, pay-and-display machines, and refuse bins. Others are making mock attacks on the police position. Chanting 'war, not peace', fists pummeling the air, between two hundred and three hundred youth at a time charge toward the police, toyitoyiing their challenge, only to disperse at the last minute and then regroup for another pass.

The police were not the only ones charged by the youths, however. Standing between them and the youth, a line of peace workers worked to diffuse the looming conflict at key flashpoints throughout the rally. Despite the looting and inflammatory aiming of police weapons at marchers, the peace workers helped the day pass without violence - with one exception. A marcher lost his life and one hundred and fifty were injured when the police lost their calm and peppered the crowd with buckshot, rubber bullets, and tear gas at the close of the rally. The newspaper headlines displayed bloody pictures of the fallen marcher and the injured the next day, but the efforts of the peace monitors were celebrated (Shaw 1993:23).

This incident underscores the complex nature of the National Peace Accord. Signed on September 14, 1991, the Accord established, among other things, a network of peace committees ranging from the national to local level, and represented a pluralistic attempt to shepherd conflict-plagued South Africa towards a democratic future. The agreement provided a needed forum for antagonistic parties to meet, offered insights into halting spiralling violence, and presented a new national vision. Yet the Accord did not even envision the brave role of the peace monitors. Their work simply emerged from extemporaneous problem solving. Moreover, because of the tendency to measure the success of the Accord by the number of fatalities instead of averted fatalities, its 


\section{Deji Olukotun}

accomplishments often go unrecognised. In the Hani rally, for example, one person died, but two hundred youth or more were ready for conflict. It is an unanswerable question how many more lives in South Africa would have been lost without the agreement.

But even the Hani incident barely touches upon the complexity of the agreement. Drawing upon interviews with key actors during the process, this section will examine the nuanced and multifaceted history of the National Peace Accord (NPA), with an emphasis on the effectiveness of the Peace Committees. The first sub-section will examine the formation of the Accord. The second will discuss the structure of the Accord by analysing the language and intent of the document. The third will assess the strengths and weaknesses of the Accord through the use of Gastrow's analytical framework. Throughout this section we will see that the Accord, while flawed, successfully transformed entrenched attitudes in the face of a rapidly changing political landscape. We will then turn to assess its legacy in the fourth section which examines current efforts to restore the spirit of the NPA in South Africa today.

\section{Origins of the National Peace Accord}

The National Peace Accord must be seen as part of the continuum of the negotiated settlement towards majority rule in South Africa. A multitude of pressures culminated in the unbanning of opposition political parties and the release of political prisoners in the early 1990 . However, ongoing conflict and an escalation in violence had resulted in nearly 700 political fatalities in the month of August alone (Ball \& Spies 1997:64). Discord over scarce resources was fomenting between blacks and whites, between and within political parties, migrant hostel dwellers and communities, Xhosas and Zulus, rival taxi services, and within impoverished townships.

Church and progressive business groups, considering themselves to be neutral mediators, each attempted to launch a negotiating forum to foster needed peace talks. Both efforts floundered. The South African Council of Churches (SACC) declared its intent to hold a national meeting of all 'strife-torn' communities in March 1991 (Gastrow 1995:15). Comprised of an alliance between Christian denominations and religious organisations, the SACC had displayed its support 
for the transition by denouncing the apartheid system, calling for a more egalitarian society, and demanding a democratic constitution at the town of Rustenburg in November 1990 (Spies 2002:20). But the failure to alert Inkatha Freedom Party (IFP) Chief Minister Buthelezi, the ANC's chief political rival, resulted in his refusal to participate in the meeting. Peace talks would have been ineffectual without the participation of these two parties so this meeting and a similar one intended for 9 May 1991 both failed to materialise (Spies 2002:39).

Progressive business forces were also unable to convene a national multiparty meeting. Representing ninety corporate business interests committed to the transfer to majority rule, the Consultative Business Movement (CBM) held a series of exploratory meetings with the government, ANC, IFP, and trade unions (Spies 2002:18). Discussions centred upon the disruption of violence to the weakened economy and private life (Spies 2002:18). But the spiralling violence derailed any possibility of national talks as the ANC issued demands of the government, alleging covert funding of the rival Inkatha Freedom Party. ${ }^{7}$ The CBM had positioned itself as capable of addressing the involved parties, but its preoccupation with maintaining the status quo also made it suspect as a sole mediator (Gastrow 1995:40).

The unilateral call of a late May peace summit by President F.W. de Klerk was equally unsuccessful. Following the demands issued by the ANC in April, De Klerk announced a national peace summit without consulting the other political parties. ANC leaders accused De Klerk of showboating before embarking on an international sanctions-lifting tour, and did not appreciate the non-consultative decision, which smacked of the authoritative apartheid era he had declared himself willing to leave behind (Spies 2002:21). Moreover, the ANC held the government responsible for causing much of the violence and shunned the lack of transparency behind the decision (Gastrow 1995:20). Three separate attempts to provide a high-profile negotiating session had failed within a short time.

At this moment the earlier initiatives of the South African Council of Churches and the Consultative Business Movement bore fruit. Church leader Reverend Frank Chikane and CBM organiser Colin Coleman, viewing De Klerk's

7 The allegations were for the most part true (Ball \& Spies 1997:6). 


\section{Deji Olukotun}

summit as a potentially destructive development, sprang to action and met with the concerned parties (Spies 2002:21). It was decided that De Klerk's conference would be framed as an 'ongoing process', and quickly followed by another, more inclusive one with the SACC and CBM serving as independent mediators (Gastrow 1995:22-23). De Klerk's half-baked summit produced two tangible results: Buthelezi's call for a network of 'peace action groups' (Gastrow 1995:24-25) and the appointment of church leader Louw Alberts to spearhead preparations for a new initiative (Spies 2002:21).

We will digress here to note IFP leader Buthelezi's suggestion for a network of peace action groups because they are relevant to our greater examination of local conflict resolution. Like the National Peace Accord, Buthelezi's idea was culled from an evolving culture of conflict resolution. The deficiencies of the apartheid system had given rise to a thriving 'other law', as Schärf and Nina (2001:13) call it, that provided the country with conflict resolution and justice:

The 'other law' has been developed and constituted in South Africa through many years of resistance, adaptation and accommodation in relation to the oppression of the apartheid state. It has also emerged as a normal response of a civil society which requires its own micro-level regulatory needs beyond state control and capacity. Last, it is a feature of a diverse society in which value systems and religious beliefs exist which are contrary to the standard western beliefs.

Peace committees had been active as 'other law' in South Africa since at least the late 1980s. A loose network of traditional makgotla and street committees thrived in the townships at the time Buthelezi demanded them. Non-state ordering mechanisms provided millions of black South Africans with access to conflict resolution on a daily basis (Schärf \& Nina 2001:7). Other communitybased and non-governmental organisations complemented the efforts of 
the makgotla and street committees. ${ }^{8}$ Buthelezi's suggestion even drew upon the positive contributions of local peace initiatives in his own constituency (Gounden 2000:75).

Returning to the formation of the document, the National Peace Accord was nearly completed by September 1991. Louw Alberts formed a thirteen member facilitating team that drew support from three members each from the ANC, IFP, and government. Five working groups hammered out details pertaining to: (1) a political party code of conduct; (2) a security force code of conduct; (3) socioeconomic development; (4) implementation and monitoring; and (5) process, the secretariat, and the media (Spies 2002:21). Junior party representatives were charged with fashioning a final agreement in order to prevent the face-saving stalemates that plagued senior leaders (Spies 2002:21). The representatives reduced numerous draft agreements down to an acceptable document by the time of the widely publicised National Peace Convention on September 14, 1991. Although extreme right and left wing parties did not participate, the Pan African Congress of Azania and Azanian People's Organisation endorsed the spirit of the final document, and twenty seven parties signed.

\section{The structure of the Peace Accord}

The text of the National Peace Accord marked an ambitious effort to stop the spiralling violence in South Africa. Signatories committed themselves to 'condemn the scourge of violence' and 'consolidate the peace process' (National Peace Accord 1991). An emphasis was placed on socio-economic reconstruction of violence-plagued areas, the investigation of particular incidents, reining in the police force, and outlawing private armies (National Peace Accord 1991). Codes of conduct were established for the political parties and the police, guidelines for socio-economic development promulgated, and implementation mechanisms approved. These measures were underscored by a declaration of basic democratic principles (National Peace Accord 1991:\$1.2). The 'fundamental' rights of

8 For example, the African Centre for the Constructive Resolution of disputes (ACCORD) worked in Mpumalanga (between Durban and Pietermaritzburg) in reconstructing a community torn by ANC-IFP antagonism. A local peace agreement was signed in 1989 and party leadership established the Mpumalanga Reconstruction Coordinating Committee as a result (Gounden 2000:74). 


\section{Deji Olukotun}

conscience and belief, free speech and association, freedom of movement and assembly, and political affiliation were agreed upon (National Peace Accord 1991:\$1.3). The media was granted wider freedom, the importance of democratic sovereignty was stressed, and the parties were reminded to behave courteously in public so as to not instigate violence (National Peace Accord 1991:\$1.4).

The signing of the National Peace Accord also marked the establishment of a new quasi-governmental body. Although various authors have offered diagrams to explain the structure, they are inconsistent and ultimately confusing, so we will confine the discussion to words. The NPA essentially worked at national, regional, and local levels. Each level contained a particular administrative apparatus.

At the national level there were three apparati. The umbrella National Peace Committee, comprised of a council of leaders, oversaw the implementation of the entire agreement. Beneath the committee, the National Peace Secretariat, headed by Antonie Gildenhuys, coordinated the peace committees throughout the nation. Parallel to the National Peace Secretariat, and also at the national level, was the Commission of Inquiry (the 'Goldstone Commission'), charged with investigating violence and intimidation.

At the regional level, three mechanisms functioned. The socio-economic and reconstruction and development sub-committee (SERD) served to address poverty and resource-based conflict. Regional peace committees were tasked with establishing local peace committees and, when possible, helping SERD to fulfil its mandate. The third mechanism of the Justices of the Peace received broad powers to investigate public complaints, mediate disputes, and refer offences to the government.

The local mechanism was arguably the most successful and interesting aspect of the National Peace Accord. At this level, local peace committees (LPCs) served to confront violence and address community concerns. ${ }^{9}$ Chapter 7 of the Accord outlined their basic functions. Beginning from the premise that insufficient instruments exist to combat violence and intimidation... at [the] grassroots

9 This explanation is drawn from a Track Two schematic diagram (Nathan 1993:5). 
level', the document then delineated specific roles (National Peace Accord 1991:\$7.1). Government involvement was deemed essential, and the National Secretariat's role of establishing peace committees was outlined. Decision making within the Secretariat was to proceed on a consensus basis (National Peace Accord 1991:\$7.3.3). Peace bodies were to be established at the regional and local levels, and both kinds of peace committees were to be representative of the communities they served. The regional peace committees (RPCs) were required to appoint a variety of church, business, and political organisations while local peace committees (LPCs) were not, only needing to be comprised of representatives 'reflecting the needs of the relevant community' (National Peace Accord 1991:\$7.4.7). The twenty-member regional peace committees also had an extremely broad agenda, including working with the Goldstone Commission, settling disputes, monitoring regional peace agreements, noting breaches of the Accord, establishing LPCs, and consulting with regional authorities to prevent violence or intimidation (National Peace Accord 1991:\$7.4.5). The Local Peace Committee agenda was much looser: creating trust and reconciliation within the community, settling disputes, reporting to the RPCs, establishing rules for rallies and marches, and liaising with local authorities for such events (National Peace Accord 1991:\$7.4.8).

Our basic understanding of the structure of the Peace Accord permits us to proceed to examine its workings in practice.

\section{Assessing the Peace Accord}

The National Peace Accord represented a commitment to peace at the highest levels of government. However, the day of its entry into force was not without difficulties, perhaps setting the tone for its three year life. Several thousand IFP supporters rallied outside on the day of the Convention, wielding the traditional weapons that their leader had just outlawed with his signature. Mandela rose to the podium and denounced the protesters, while Buthelezi, instead of apologising, intoned: 'Wherever the king is, the people come' (Financial Mail Survey 1993:7). Buthelezi then accused Mandela of breaching the code of political conduct after Mandela called him a 'surrogate' to the government (Financial Mail Survey 1993:40). 


\section{Deji Olukotun}

The Accord otherwise got off to an acceptable start. Within a short time, the marketing committee developed the distinctive blue two-dove mark that came to represent the process. Television and newspaper advertisements explained the basic mechanisms of the Accord and the parties attempted to fulfil its mandates. The investigatory Goldstone Commission, after launching 467 investigations and filing 46 reports (Stober 1995:21), fostered an agreement for party rules governing mass rallies (Financial Mail Survey 1993:18), and eventually revealed the existence of the government-sponsored 'third force' that threatened to derail the negotiations. The National Secretariat held 38 formal meetings in its first year (Stober 1995:12), and spawned eleven regional peace committees and 263 local peace committees by 1994 . The regional and local committees absorbed the impact of violence on a daily basis, frequently representing the sole line between, according to Collin Marks (2000:20), 'a fragile equilibrium and chaos'. The committees' individual achievements are remarkable but also anecdotal and plagued by the difficulties inherent in measuring the absence of violence. Except for Mandela's call to revitalise the agreement following negative media coverage in June 1993, most aspects of the Accord functioned well (Ball \& Spies 1997:26).

The peace monitors served as the Accord's most visible contribution to civil society. Not envisioned within the text of the document, but also not anathema to it, a network of monitors developed along with the regional and local peace committees. They identified themselves with colourful bright vests and frequently placed themselves in danger at marches and potentially explosive events. A last minute decision by the IFP and an injection of funds from the British government enabled about 18500 monitors and 1930 marshals to oversee the April 1994 elections (Siebert 1994:36). Their ability to operate communications centres facilitated the distribution of ballot papers and ensured peaceful journeys to the ballot. International observers were obviously impressed. Scotland Yard chief superintendent David Gilbertson, for example, declared that 'the peace structures probably saved the electoral process at an operational level' (Garson 1995c:14). Gerrit Nieuwoudt, a police superintendent who sat on the Western Cape Regional Peace Committee, echoed these sentiments. The police monitors 
'gave an awareness of being watched,' he remembered, 'and this helped all the parties in difficult situations. 10

Interestingly, the stated goal of the Accord to 'consolidate the peace process' also resulted in its demise. The start of the CODESA (Convention for a Democratic South Africa) talks immediately following the Accord and the later Multiparty Negotiations Forum sessions both sapped the NPA of momentum. The interim transitional government, without explanation or dialogue, began closing down the National Peace Secretariat as early as 1994 (Spies 2002:25). The task of fostering a political climate conducive to the transition had more or less been accomplished. It was presumed that the expected democratic institutions would replace the structures with accountable local governments, but this was never expressly stated (Spies 2002:25). Leaders within the Secretariat lamented the decision and made unanswered pleas for financial support from the business community, hoping to fund a R35 million shortfall (Garson 1995b:14). However, by December 1994 the entire apparatus was dismantled. The KwaZulu-Natal Provincial Legislature was the sole government that continued its regional and local peace committees, with a R5,5 million operating budget for 1995 (Spies 2002:25). ${ }^{11}$ Thousands of volunteer and full-time peace workers scrambled for prized positions in the new 'peace industry' or, with luck, returned to their old posts.

It suffices to say that the rich history and structure of the National Peace Accord have been examined at length. Two scholars who participated in the process, Peter Gastrow and Susan Collin Marks, wrote extensive analyses. In Bargaining for Peace, Gastrow offers the perspective of an insider conflict resolution theorist well-versed in the Accord's political development. Collin Marks' Watching the Wind presents a more informal, experiential view of a member of a Regional Peace Committee that is invaluable for its practical insight on day-to-day peace efforts. Because of its more systematic analysis we will utilise Gastrow's work as

10 Interview with Gerrit Nieuwoudt, Police Superintendent of Kraaifontein South African Police Services (25 Jan. 2006).

11 See also MacGregor 1995. 


\section{Deji Olukotun}

a framework to assess the effectiveness of the agreement, followed by an analysis by another scholar for balance.

\section{Peter Gastrow's objectives}

Gastrow suggests utilising the main objectives of the Accord as a matrix. His reading of the agreement found that it intended to (1) eliminate political violence through the peace committee network; (2) promote democratisation by fostering a climate of tolerance; and (3) facilitate reconstruction and development in strife-torn communities (Gastrow 1995:57).

\section{Eliminating political violence}

On the face of things, the first objective of eliminating political violence appears not to have been reached. Statistics indicate that violence was neither eliminated nor lessened. The years 1991-1993 saw an increase in political fatalities from 2706 in 1991 to 3347 in 1992, and from 3347 to 3794 in 1993 (Ball \& Spies 1997:64). Gastrow notes that most of these deaths were based in the hot zone of KwaZulu-Natal and the Pretoria-Witwatersrand-Vereeniging area, where 'political rivalry is at its fiercest', and this clouds the fact that the rest of the country may have succeeded in stemming violence (Gastrow 1995:78). But this observation misrepresents the fact that over 60 percent of the national economy was located in those regions at the time (Gastrow 1995:77). In other words, it seems natural that conflict should have occurred where the most resources were at stake, even if most were controlled by the white minority. (It also seems tautological to say that violence happened where violence was at its worst.) Ball and Spies (1997:12) shed some light on this issue with respect to local peace committees:

Efforts to establish LPCs often ran up against a 'Catch-22' situation. Where tensions existed but violence was latent, communities often questioned the need for peace committees. Once violence flared, however, community leaders were often more willing to have committees established, but the polarization resulting from the violence greatly increased the difficulty in establishing committees. 
The regions of KwaZulu-Natal and Witsvaal, they observe, were typical of this Catch-22 difficulty. Regional peace committees in these areas were fraught with internal politics and accused of partisanship. Because of the reactive nature of local peace committees, which were set up to combat violence as it flared, many were created when the conflict escalated to intractable levels of conflict and mistrust (Shaw 1993:6). In a small town in the Transvaal, for example, some local organisations felt there was no need for a peace committee since there was no violence, but demanded one when violence erupted. By the time it was established, it was ineffective against the entrenched positions of the parties involved (Shaw 1993:7). Gastrow's regional analysis of the violence also detracts from the fact that, despite this Catch-22 phenomenon, LPCs in those violencetorn regions were often the most effective committees in the country once operational, as judged by the frequency of participation, frequency of meetings, and success in resolving disputes (Shaw 1993:30).

Another, more valid qualification Gastrow makes is that political fatalities are not an adequate measure of violence. The patterns of violence changed, particularly in the sense that overt, daytime killings were replaced by underground attacks and massacres perpetrated by the then anonymous Third Force. According to a Financial Mail Survey, these were groups of 'well-armed, well-organised gunmen who inevitably melted away after the event to spark a wave of retaliatory violence against opponents of those attacked.. ${ }^{12}$ Revenge killings and assassinations became the norm (Shaw 1993:9). The underground violence presented issues of causation and procedure that hampered the Goldstone Commission and prevented the perpetrators from being brought to justice for lack of witnesses (Shaer \& Nossel 1992:19). The police and mercenary members of the Third Force also tended to come from outside the communities, and therefore could not be confronted in local forums.

This observation of the changing patterns of violence is related to a much larger point. The nature of peace work makes it impossible to measure exactly how many political fatalities were prevented. Any attempt would by nature be hypothetical

12 The third force was later revealed by the Goldstone Commission to be operated by members of the South African Police (Gastrow 1995:80-81; Financial Mail Survey 1993:4). 


\section{Deji Olukotun}

and counterfactual. For example, in the discussion of the Chris Hani marches that opened this section, it seems fairly clear that the intervention of the peace monitors in the face of the toyi-toyiing youth may have prevented a blood bath. But there is also the remote possibility that the youth would not have charged at all if they had not known the monitors would keep things in order. 'Generally speaking', Secretariat head Dr. Antonie Gildenhuys explained, 'measuring the impact of the peace structures is difficult, because some of our successes are non-events' (Garson 1995a:16). On the other hand, Justice Goldstone, head of the Investigatory Commission, warned that if there had not been tens of local dispute resolution committees operating throughout the country, I don't think any sensible person could doubt that the level of violence would be much worse' (Financial Mail Survey 1993:20).

Efforts are made to assess the potentially 'worse' violence by pointing to the number of monitors and local peace committees in existence (about 18500 and 260, respectively) at the time the Secretariat was closed in 1994. But this argument is also subject to criticism. The mere existence of an institution does not demonstrate its success; the bureaucratic quagmire of the apartheid government can attest to that fact. That the LPCs were voluntary does bolster the point somewhat, but some communities felt the committees were forced upon them. ${ }^{13}$ The existence of empirical research might have helped resolve this problem of metrics. However, given the dramatic and sudden closure of the Secretariat, much of the valuable data, such as meeting minutes and local reports, were lost as a handful of officials closed the project down (Spies 2002:25).

\section{Promoting democratisation and a culture of tolerance}

The second goal of the Accord identified by Gastrow pertains to its ability to promote democratisation and a culture of tolerance. This goal is inherently less measurable than the goal of eliminating violence, yet it is also the area in which the Accord appears to have met with the most success. The single most challenging and remarkable aspect of the agreement appears to have been the ability to change attitudes. On the national level, the National Peace Committee

13 Shaw (1993:7) cites the example of Bruntville, Natal, in which the community considered the establishment of an LPC to be an intrusion. 
provided a forum in which opposing leaders could meet informally even after talks had broken down. The mutual commitment to the spirit of the Accord permitted, according to Spies, 'channels of communication to remain open' (Spies 2002:20). The establishment of face-to-face relationships also proved valuable at the regional and local levels. Political rivals suddenly found a neutral forum in which to express their views without losing face, and community members began a tentative dialogue with the South African Police Services, or addressed non-political problems from a conflict resolution perspective.

Indeed, the police represent an excellent example of the ability of the Accord to change attitudes. Chapter 4 of the agreement stipulated a detailed code of conduct for the police forces that required, among other things, upholding basic rights and liaising with members of the community when possible, both novel responsibilities. They were also required to wear identifiable badges and patrol in clearly marked cars, removing the ability for surprise attacks and increasing accountability. Minimum force, adhering to unprejudiced conduct, avoiding corruption, and adopting an altruistic, community-oriented attitude were other important tenets (Collin Marks 2000:165). Joint Operations Communication Centres alerted community members to roadblocks and search actions, while political parties informed police of coming rallies (Ball \& Spies 1997:28). Sometimes the very act of attending regional or local peace committee meetings was enough to break down barriers. Seating arrangements manipulated personal space and placed former enemies next to each other (Collin Marks 2000:159). Collin Marks (2000:159) recalls one particularly revealing incident watching an apartheid activist sit deliberately next to an old enemy:

Stewart walked in, hesitated, his eyes sweeping the circle, and made his decision. He walked toward a vacant seat next to a police major. He sat down and turned to greet the police major before acknowledging the warm welcome of colleagues and friends. Only a handful of people in the room knew that he had chosen to sit beside his former torturer.

The culmination of encounters such as these was a drive towards community policing. Committed by their leaders to adopt new methods of policing in 


\title{
Deji Olukotun
}

the spirit of the Accord, dialogue with police increased recognition that they were meant to serve, rather than terrorise their communities (Collin Marks 2000:169). This ran directly counter to their apartheid-era training, which implored them to seek out - and often destroy - government opposition (Collin Marks 2000:161-162). Yet by the time of the elected constitutional government, community-police bridges had been forged in the New Police Act (Collin Marks 2000:176). A police officer sitting on the Western Cape Regional Peace Committee recalled that ' $[t]$ he police were used to being on their own. Now they gathered input from others. This attitude slowly filtered upward to the management'.

Local peace committees in particular made a variety of differences at the community level. Local politics were made less divisive by the neutrality of the forum (Shaw 1993:8). Rumours were dispelled through transparency before they were inflamed (Ball \& Spies 1997:20). LPCs also provided a needed administrative apparatus in resource-deprived communities (Shaw 1993:8), furnishing telephones, faxes, and rapid response vehicles (Spies 2002:25). The notorious taxi rivalries of the Western Cape and squatter conflicts in the Transvaal were, at least temporarily, resolved (Shaw 1993:8). Several thousand committee members also benefited from training sessions held across the country (Gastrow 1995:75), learning practical conflict resolution skills that helped increase local empowerment. Again, many of the accomplishments are anecdotal, but on the whole, local and regional committees carried out their mandates, as Ball writes:

\begin{abstract}
[A] comparison of the official mandates with the functions actually carried out by the committees clearly demonstrates that despite significant difference in the degree of success registered by individual committees in fulfilling their mandates, as a group, the regional and local peace committees did manage to perform most tasks specified in the NPA (Ball \& Spies 1997:9).
\end{abstract}

Most regional and local peace committees were successful in upholding the letter of the agreement, although not all. Some committees were underinclusive, neglecting the important voices of refugees and migrant workers, as well as youth (Ball \& Spies 1997:37). But due to the vague language governing the LPCs, flexibility permitted adaptability to fluctuating conflict climates. A committee 
could oversee the installation of water taps in a squatter settlement, address allegations of police brutality, and resolve hostel disputes at the same meeting.

However, the ability of the peace committees to foster democratic processes should not be confused with the internal structure of the NPA. The Accord was essentially structured as a top-down mechanism, imposed from the highest levels of society to the local level. In some ways, particularly with respect to the police, this was a positive development because lingering apartheid structures could be resistant to change. But, in a negative sense, this prevented the insights of the local and regional structures from influencing national level decision making. It would have been simple to include LPC members on RPCs, for instance, and for RPC members to be represented at the Secretariat level. But national level members were appointed, and LPCs were generally consulted by RPCs, rather than represented on their structures. This denied the very real impact that these mechanisms were having on the communities, and prevented the adoption of practical insights. Perhaps if members of the local committees had been present at the national level, the interim government would not have been so quick to scrap the Accord.

A successful argument could be made that the Accord suffered from a lack of internal commitment to diversity as well. There was a severe dearth of women within the structures of the Accord (MacGregor 1995:53). Its facilitation by the Consultative Business Movement also appears to have left its imprint as a top-down structure. Different scholars have noted its close resemblance to a corporate board and its failure to incorporate the interests of its consumers (Midgley 1992:1, 9; Shaw 1993:15). Fund disbursement to local level structures was therefore appallingly low (Shaw 1993:16). The national level leadership also seems to have been overwhelmingly white. The key cabinet members - Judge Goldstone (of the Investigatory Commission), Gildenhuys (of the National Peace Secretariat), and John Hall (Chairman of the Accord) - while progressive, certainly did not reflect the envisioned Rainbow Nation. These leaders were complemented by the appointed representatives of the IFP, ANC, and NP, but non-whites were the majority in the country. Perhaps the overall lack of diversity can be explained by the political affiliation of minorities capable of wielding 


\section{Deji Olukotun}

such power, but this is somewhat unlikely, and it does not answer the problem of gender disparity.

Despite its shortcomings, the National Peace Accord does appear to have effected widespread change at an institutional and attitudinal level. It readied the nation for coming transformation at a time in which spiralling violence seemed to preclude the possibility.

\section{Socio-economic development and peacebuilding}

The third and final criterion offered by Gastrow of the ability of the Accord to facilitate reconstruction and development in strife-torn communities, does not appear to have been reached. This criterion relates to the arena that Johan Galtung called 'peacebuilding. Peacebuilding entails the transformation of the structural conditions that foment conflict (Shaer \& Nossel 1992:2). Class violence, entrenched attitudes, and access to resources must be addressed to prevent conflicts from resurfacing in a new form. The Accord does not seem to have satisfied these requirements.

Most studies of the NPA distinguish between its ability to resolve symptoms of violence and resolve structural causes of violence. 'The Accord', a monitoring team from International Alert determined, 'at best addresses the symptoms of political violence, but it cannot overcome the structural causes of violence' (International Alert 1993:3). Ball seconded this assessment, writing that 'the structural causes of violence and the struggle for power among the major political parties limited the capacity of the committees to significantly reduce violence in South Africa prior to the 1994 elections' (Ball \& Spies 1997:13). The Accord and its foot soldiers, the peace committees, acted as a temporary band-aid to replace failed apartheid and political party attempts to halt violence.

Yet the Accord did contain textual provisions to combat these structural difficulties. The Accord's original Preparatory Committee boasted that it did 'creat [e] the structures' and could serve as 'a vehicle which [would] bring peace if

all South Africans work[ed] together in those structures' (Financial Mail Survey 1993:11). The Socio-economic and Reconstruction and Development subcommittee (SERD) was intended to prevent the recurrence of violent conflict by 
repairing communities crushed in its wake, before the resulting resource drain created more conflict. This structure-building activity was to be carried out while simultaneously addressing the other issues covered in their mandate.

However, SERD failed to uphold the letter of the agreement in most respects. The business community, with all the lip-service it paid to economic empowerment, contributed negligible resources. ${ }^{14}$ The undivided attention required of the LPCs and RPCs ultimately prevented the initiation of SERD projects, as they were 'too bogged down in crisis management to systematically address reconstruction' (Garson 1995c:8). International Alert pointed to the difficulty of the task without the securing of additional personnel for the express purpose (International Alert 1993:13). Shaw also notes that even the presence of personnel and funds might not have solved the problem. There was some evidence that development projects were not necessarily 'conflict-free', and were capable of fomenting discord, as the death of four on the East Rand over resource distribution demonstrates (Shaw 1993:22).

In short, Gastrow's third identified goal of rebuilding strife-torn communities was not satisfied.

\section{Concluding thoughts}

While the National Peace Accord steered the nation towards the transitional government, creating needed space for negotiations, it was flawed. The top-down structure was fashioned behind closed doors and created problems of 'ownership' in some communities (Mbileni 1993:16). Communication was hampered by a failure to use radio and to translate the document into indigenous languages. The initiative also lacked enforcement mechanisms capable of giving it 'bite'. At best, even for the Goldstone Commission, officers could refer matters to criminal or civil courts to impose fines. This meant that it relied upon opprobrium and condemnation to achieve results, when tougher measures were necessary. Finally, while churches often diffused tensions within their flocks, the business

14 Interview with Peter Gastrow, Director, Institute for Security Studies, Cape Town (13 Sep. 2005). 


\section{Deji Olukotun}

community offered nothing more than management skills and fell short of any other meaningful contributions. ${ }^{15}$

Such flaws were an inevitable manifestation of an improvised negotiation process. At no time were the parties to the Accord a monolithic bloc; complexity and fluctuation characterised it from the outset. Nor does any such experiment appear to have been tried before. The initiative changed over time from merely meeting evolving needs to a structure that placed responsibilities on state and non-state actors. ${ }^{16}$ It acted as a stopgap measure to fill a swiftly developing power vacuum as the apartheid government lost its legitimacy. Measuring the success of the agreement is challenging, but those who participated in the process appear to agree that the peace committees 'saved lives' (Ball \& Spies 1997:20).

This testimonial, of saving lives, makes it especially disappointing that the interim government dismantled the structure in its haste. Countless primary source documents were lost that may have proven useful during the Truth and Reconciliation Commission process or, simply, bore witness to a turbulent time. 'I thought the Peace Committees should have continued,' Peter Gastrow said. 'I understand that the new government did not want old vestiges of the previous regime to continue, but that does not mean we should discard conflict resolution in local areas. ${ }^{17}$ After the disbursement of nearly R65 million and the creation of an extensive peacebuilding network (Ball \& Spies 1997:65), committing more effort to understanding the effectiveness of the Accord seemed well within the elected government's grasp.

15 Interviews with Gerrit Nieuwoudt and Peter Gastrow.

16 A few small examples illustrate this point. The annual budget stood at US\$12 million by 1993 and was administered by the Department of Justice. However, as delays plagued its implementation, financial control was transferred to the National Peace Secretariat. The agreement was also altered slightly by the passage of the Internal Peace Institutions Act of 1992, which gave it official government recognition. The Internal Act did not mirror the original text, nor did the Accord's implementation in practice with its top-down management style typical of the outgoing authoritarian regime. The provisions on the regional level Justices of the Peace in particular were especially broad and could have led to the abuse of powers. In addition, certain mechanisms were established before others, further demonstrating its fluctuating nature. See Spies 2002:22; Midgley 1992:1, 7.

17 Interview with Peter Gastrow. 


\section{Wedding non-governmental conflict resolution to the state}

The conflict resolution community in South Africa has long been intertwined with the state. In the colonial era, indigenous conflict resolution practices were mediated by the state through indirect rule that was further enforced through rural and urban divides (Schärf \& Nina 2001; Seekings 2001:72). During apartheid, there were several marked shifts by the conflict resolution community in response to state action. Indirect rule persisted in some areas (Moses 1990:44) while in others conflict resolution practitioners developed a parallel informal sector. Forms of popular justice, community courts, and non-governmental organisations all functioned against a backdrop of state activity. These 'other' activities proliferated in

the economic sphere (the informal sector), informal insurance (burial societies), informal banking (savings clubs), the welfare sphere (informal child- and old-age care), informal health (traditional healers and herbalists), informal housing (sometimes orchestrated by shacklords) among others (Schärf \& Nina 2001:3).

Following the transition from apartheid, discussion began about officially recognising these formally subversive structures (Nina 1995:18). The new, majority-run state offered the possibility of ensuring them a more permanent role. Its command of resources could sustain financially-strapped conflict resolution organisations (Jantzi 2004:194).

The South African Law Commission began investigating the possibility of wedding non-state conflict resolution to government structures in 1997. Project 94, 'Arbitration: Community Dispute Resolution Structures', sought to consult both South African and international authorities on the appropriate state response to non-state dispute resolution organisations. The Commission held workshops around the country in which practitioners, scholars, traditional African authorities, and jurists voiced their opinions. 


\section{Deji Olukotun}

This section seeks to explore the future of conflict resolution in South Africa. It strives to identify some of the key themes that emerged from the Law Commission's discussions and critically analyse the proposed solutions. It is submitted that state involvement in community dispute resolution structures may improve access to justice and help transform problems, but will be hampered by inherent practical difficulties in standardising a diverse community. A 'New National Peace Accord' is unlikely to arise in the near future.

\section{Project 94 and its resolutions}

Project 94 represented an effort by the state to include non-state actors in the provision of justice. The investigation evolved as part of an ongoing project initiated by the Minister of Justice in 1994 to assess alternative methods of dispute resolution (SALC 2005). Initially convened to study arbitration, the study was broadened to include alternative dispute resolution (ADR) and, by 1997, had evolved into a three-pronged approach (SALC 2005:1).18 ADR and the civil law, family mediation, and community courts would each be studied separately by a select committee, the Project Committee on Alternative Dispute Resolution (SALC 2005:2). The committee decided to begin its inquiry into community courts first, and forwarded a variety of pertinent questions to the public. 'Community courts,' were defined as

popular justice structures, or the many informal tribunals existing outside the formal legal structures, such as street committees and yard, block or area committees operating in urbanised African townships and informal settlements (SALC 2005:3).

Among the committee's concerns were the level of state involvement, public perception of community courts, the general ability of community courts to patch up the justice system's shortcomings, applicable jurisdiction, procedures, and the regulation of interaction between the community courts and the formal judicial system.

18 The Commission was also supported by the 1998 White Paper on Local Government. See Griggs 2003:129. 
Several relevant themes emerged from the consultation process. There was an overriding concern with access to justice in the formal system. Access was found to be inadequate along geographical, financial, attitudinal, educational, and cultural lines. Geographically, the formal justice structures were situated too far from popular centres (SALC 2005:15). This was further compounded in rural areas, where participants were forced to travel long distances and attended the committee's workshops at great hardship. The formal courts also demanded financial resources that were beyond the average South African so it was difficult to secure attorneys and pay court fees. Attitudinally, court officials could be dismissive of people's complaints or bungle procedures through improper training. ${ }^{19}$ Even when functioning well, these procedures also could lead to the 'snowballing' of disputes, such that they became larger and more destructive:

When someone wants to stab you and you rush to the police to report, they tell you that he must first stab you and only then you can come and report the matter to them. These people are not stopping crime and it is discouraging (Seekings 83). ${ }^{20}$

In the area of education, many citizens were lacking in knowledge about their constitutionally guaranteed rights. Court officials also did not understand witchcraft and other relevant cultural issues and unnecessarily intervened (SALC 2005:19). Their ignorance underscored a general lack of communication with existing non-state dispute resolution structures (SALC 2005:19). Language difficulties also made the courts unappealing. For example, in the North West Province, the participants preferred to use Setswana, their native tongue, and were forced to use an interpreter (SALC 2005:22). Finally, the courts were overburdened and inefficient and tended to favour whites over blacks, perpetuating class differences (SALC 2005:25).

19 For example, in the area of domestic abuse, Zarina Majiet of Mosaic, a Western Cape organisation, explains that Xhosa policemen sometimes impute ownership to an abusive husband over a spouse, when they are in fact required by law to press charges. Interview with Zarina Majiet, Director, Mosaic (27 Sep. 2005).

20 Seekings 2001:83, quoting Siegfried Manthata. 


\section{Deji Olukotun}

Non-state, informal dispute resolution mechanisms addressed some of the shortcomings of the formal system. They were trumpeted as more empowering, adhering to traditional values, promoting reconciliation and restoration, as being cheaper and speedier, providing better operating hours, and as possessing a community-wide outlook instead of breaking down grievances into purely individual cases (SALC 2005:27). Procedures were common-sensical and more flexible, and language barriers were not at issue (SALC 2005:31). And, while these community dispute resolution structures were normally utilised by blacks, this was not always the case. For example, in KwaZulu-Natal, white participants professed a preference for the king's traditional courts over the formal state structures (SALC 2005:30).

However, the informal system was not without its own share of problems. The diversity of community dispute resolution structures prevented defining them with satisfaction (SALC 2005:39). Traditional courts were found to discriminate against women, and vigilantism plagued certain areas (SALC 2005:75). Lungisile Ntsebeza, who has written extensively on the role of traditional authorities in South Africa, expressed his own concerns:

My bottom line is that they must be democratic, legitimate, transparent and can be challenged. My own reservations about traditional institutions are that they are undemocratic and not transparent. If they can be made transparent, with competent leaders, not because of birth, they would be fine. But the nature of traditional courts is that they are appointed by birth right. I am sure that they worked for small groups in the past. But if it worked then, you must look at the context... The same holds true for street committees. Many were not democratic or representative. They were kangaroo courts - we cannot beat about the bush about that. ${ }^{21}$

Many community dispute resolution structures functioned in a particular context that benefited from their activity. But the nation is not the same today as it was before colonialism or during apartheid. Decisions made in community

21 Interview with Lungisile Ntsebeza, Associate Professor of Sociology, University of Cape Town (6 Feb. 2006). For a more detailed expression of these sentiments, see Ntsebeza 2005. 
courts also lacked a necessary coercive element, such that members against whom decisions were made could simply leave the area (SALC 2005:16). Allegations of corruption and abuse of power further undermined the informal systems. Oddly, some participants found that informal structures were not formal enough. Certain structures lacked set guidelines and policies, making outcomes unpredictable and insufficiently coercive (SALC 2005:25). And in some areas, such as the Free State, both informal justice and formal justice were non-existent (SALC 2005:33).

\section{The Draft Bill}

Having consulted the South African community, the South African Law Commission then moved to distil the multiplicity of suggestions down to a workable praxis. The combination of professional, juridical, and scholarly contributions was eventually collapsed into a draft bill and several concrete proposals. The Law Reform Commission elected to suggest a loose 'framework' within which community dispute resolution structures (CDRSs) could operate. It opined that

any attempt to regulate community dispute resolution structures by prescribing to them how they should be formed, how they should operate and by creating a bureaucracy to enforce compliance with these prescriptions would be a mistake. Not only would such a course of action undermine genuine community based initiatives, but also the community support which gives them their strength (SALC 2005:100).

The framework and the related Draft Bill strongly emphasised training over direct funding and avoided meddling with formal law. The report acknowledged South Africa's lack of state resources and that access to justice was directly linked to class. While some CDRSs resorted to vigilantism, most did not and could serve a 'useful purpose' in furthering access to justice (SALC 2005:102). Accordingly, the state should grant 'explicit recognition' to CDRSs 'in principle' (SALC 2005:102). Recognition would be furthered by: 
(a) asking whether a structure needed assistance in linking with formal structures;

(b) arranging meetings with formal structures for referral purposes;

(c) helping CDRSs apply for funding, use of facilities, training, and expanding criminal jurisdiction;

(d) promulgating a 'code of conduct' by which the CDRS abides;

(e) attempting to prevent duplicating functions, particularly in rural areas; and

(f) promoting the Small Claims courts in the townships (SALC 2005:103).

\section{Comparing the texts of the Draft Bill and the National Peace Accord}

In the preceding sections, we examined the context of the Draft Bill and National Peace Accord. Each section identified the events that culminated in the shaping of these documents, described and analysed their work in practice, and attempted to assess their outcomes. It may prove useful to briefly compare the co-texts of each document as well. In other words, based solely on the texts of the Accord and the Draft Bill, are there any insights that may be gained?

The National Peace Accord is a complex document. Its preamble contains a religious component, delineates rights, outlines specific problems confronting the nation, and focuses on local level solutions (National Peace Accord 1991:Preamble). It also creates several mechanisms - the Goldstone Commission, peace committees, and Justices of the Peace - and stipulates the means by which the mechanisms may be given effect. A full chapter outlines the rights required of a multiparty democracy and emphasises consultation with affected communities. More relevant to the Draft Bill, Codes of Conduct are enumerated that place duties on the police, political parties, and state authorities (National Peace Accord 1991:chapters 3-5). Breach of the Accord would be resolved by eventual referral to an arbitrator. 
The Draft Bill contains several differences. There is no mention of God or religion. Rights are not discussed. New mechanisms are not created so much as recognised: the Minister of Justice and Constitutional Affairs may grant recognition to a CDRS or withdraw recognition from a CDRS. Police are addressed in both documents, but in significantly varying degrees. The Accord discusses the police in detail, underscoring the importance of their envisioned role. By contrast, there is only very brief mention of the police in the Draft Bill. This is unusual in that both documents express a concern for unusual criminal cases. The Accord provides for 'Special Criminal Courts', while the Draft Bill denies jurisdiction to CDRSs in major criminal cases.22 But while the Accord speaks to a clear link between criminal cases and the police, the only role for police in the Draft Bill is for a 'liaison officer' to facilitate discussion between the CDRSs and the formal court system. Another distinction may be found in the Codes of Conduct. Like the National Peace Accord, promulgating a Code of Conduct is identified as central to the Draft Bill. However, while the Accord stresses the possibility of violations by both the state and political parties, the Bill seems to be wholly suspicious of the CDRS alone, perhaps because the state's underlying Code of Conduct is the Constitution.

Another relevant point is that several political actors signed the Accord. The Draft Bill, which would become democratic law if ratified, would represent an agreement between the state and its people. The Accord stipulated referral to an arbitrator if the signatories acted out of line. The only enforcement mechanism in the Draft Bill appears to be amending the constitution. A sub-agreement, or sub-contract, between the state and the CDRSs could be withdrawn by either side, as we have seen. ${ }^{23}$

Revisiting the contextual themes outlined earlier in the article - for example, the numerous political forces acting in the Accord - may explain some of the distinctions between the two documents. But the reluctance to relinquish state

22 The Special Criminal Courts never materialised.

23 The Draft Bill also contains a specific bias against arbitration because of its 'inconsistency' in resolving disputes in CDRSs. 


\section{Deji Olukotun}

power to CDRSs and the tendency to ignore the role of the police in the Draft Bill are worth noting.

\section{Summary}

The Draft Bill that emerged from Project 94 would result in the recognition of a long existing non-state ordering community. These community-empowering mechanisms would be legitimised by the state and acknowledged for their contributions to conflict resolution in South Africa. Criminal jurisdiction would be extended so that communities could nip small disputes before they developed into large scale conflicts. Justice might be better standardised through increased adherence to constitutionally-aligned codes of conduct. Local mechanisms with inadequate coercive power might benefit from state enforcement, and dialogue would be fostered between the informal and formal sectors.

Yet the Draft Bill contains significant weaknesses. The most common aspect of informal justice is its lack of sustainable funding (Jantzi 2004:194), which the state would not provide with the Bill. The state would incur few new responsibilities other than the training of formal structures on how to interact with non-state structures. (Indeed, training has become a buzzword in the government with its own inherent difficulties of measurement.) The state would also be officially outsourcing justice to these mechanisms, potentially permitting it to wash over its duty to expand formal justice. The relationship of the informal sector to the existing legal aid, family courts, equity courts, and sexual offences courts has not been sufficiently determined. Compounding this issue is a general lack of access to all of the formal institutions.

Our examination of the National Peace Accord has shown that many of these difficulties may be fatal to the proliferation of local conflict resolution structures. Significant failings of the Accord pertained to, among other things, peacebuilding and the initiative's hasty demise. Peacebuilding in local communities failed because of inadequate funding. The peace committees were dismantled when they had proven on the whole successful, against better judgment, in part because there was a lack of communication from the local to the national level. The Draft Bill suffers from similar flaws. There is an underlying problem of rapid exit of the shared apparatus by either local groups or the government (but 
more likely the government). The bill also does not seem to adequately mandate communication between formal and informal structures. Communication may need to be required at periodic intervals, with ongoing monitoring. And, ultimately, the bill seems to require de facto subservience by CDRSs to the formal hierarchy. They would still be, it seems, 'second class justice'.

Perhaps the Bill would be better served by attempting to fill the gaps left by the formal system. Formal legal structures address criminal issues and some specific civil matters. Legal aid is heavily weighted towards criminal matters, however, and the civil courts are not as geographically widespread. CDRS mechanisms that address the cases that slip between these institutions may potentially be more easily wedded to formal structures. As access expands, these CDRSs could be formalised. The difficulty with this approach is that it would deny the flexible nature of many CDRSs. Limiting jurisdiction might inhibit both the coercive power of the courts and their problem-solving abilities. Searching for root causes of conflict often requires blending remedies across civil and criminal lines.

\section{Conclusion}

The places to which people already go to resolve conflicts - the 'other law' - have been providing justice to South Africans for decades. But recognition of these ordering mechanisms is itself beset with difficulties. The 'other law' is pluralistic in nature, making it difficult to make naturally subversive and organic entities conform to the formal justice system. Guidelines may provide some certainty, but this does not disguise the uncertainty of the political process itself - the Draft Bill may disappear once it enters the legislature. (At the time of this writing, the South African Law Commission claims to be investigating Project 94 but there has been no official activity either in the legislature or the courts). ${ }^{24}$ 'It was overkill', explained Project 94 member John Cartwright. 'We could not

24 Similar draft legislation by the South African National Civics Association, for example, never bore fruit (Nina 1995:18). 


\section{Deji Olukotun}

figure out how to mesh with government structures.' ${ }^{25}$ The creation of a new National Peace Accord therefore appears unlikely in the short term.

This article should be read with some caution. In the 'past', we examined a quasigovernmental body and the 'future' assessed linking the state to community organisations. A strict analysis might critique this as comparing apples to oranges. The article essayed to overcome these differences by identifying key themes: geographic differences, business efforts, strategic positioning, funding trends, and attempts to eliminate structural challenges. The hope is that the reader will leave with a better understanding of the conflict resolution community and of the complexity of issues facing South Africa today. If nothing else, South Africa's unbridled forays into conflict resolution have been, and continue to be, incredibly inspiring.

\section{Sources}

Ball, Nicole \& Chris Spies 1997. Managing Conflict: Lessons from the South African Peace Committees. Washington, D.C.: Overseas Development Council and Centre for Conflict Resolution at Cape Town.

Bremner, David \& Philip Visser 1992. Approaches to Community Conflict Resolution: Process Design Choices in Phola Park and Meadowlands. Paper presented at the Fifth Annual Conference of the South African Association for Conflict Intervention (SAACI), University of Port Elizabeth, 25-28 November 1992.

Centre for Conflict Resolution 2004. Seminar Report: South Africa in the Post-Apartheid Decade. Nov 2004. Cape Town: Centre for Conflict Resolution.

Cock, Jacklyn 2001. Butterfly Wings and Green Shoots: The Impact of Peace Organisations in Southern Africa. Track Two 10 (1).

Collin Marks, Susan 2000. Watching the Wind: Conflict Resolution during South Africa's Transition to Democracy. Washington, D.C.: U.S. Institute for Peace.

Financial Mail Survey 1993. The National Peace Accord. 9 Apr 1993.

Garson, Phillipa 1995a. Interview of Dr. Antonie Gildenhuys. In: In the Name of Peace. Johannesburg: Sowetan.

Garson, Phillipa 1995b. Out in the Cold. In: In the Name of Peace. Johannesburg: Sowetan.

Garson, Phillipa 1995c The Greatest Gift of All. In: In the Name of Peace. Johannesburg: Sowetan.

25 Interview with John Cartwright, Communications Director, Community Peace Programme (July 2005). 
Gastrow, Peter 1995. Bargaining for Peace: South Africa and the National Peace Accord. Washington D.C.: U.S. Institute for Peace.

Gounden, Vasu 2000. The South African National Peace Accord: A Moment of Peace in a Protracted Process. In: Garcia, Ed (ed), Pilgrim Voices: Citizens as Peacemakers. Manila: Anteneo de Manila University Press.

Griggs, Richard 2003. Lessons from Local Crime Prevention. Newlands, South Africa: Open Society Foundation for South Africa.

International Alert 1993. Mission to South Africa to Evaluate the National Peace Accord and its Peace Structures. Report, May 1993. London: International Alert.

Jantzi, Vernon E. 2004. What is the Role of the State in Restorative Justice? In: Zehr \& Towes 2004.

MacGregor, Karien 1995. The Work Continues. In: In the Name of Peace. Johannesburg: Sowetan.

Mandela, Nelson 1994. Long Walk to Freedom. Randburg, South Africa: Macdonald Purnell Ltd.

Mbileni, Chris 1993. Northern / Eastern Transvaal. Track Two 2 (2).

Midgley, J. 1992. Implementing the Peace Accord: A Guide to Dispute Resolution Committees. Paper presented at the Fifth Annual Conference of the South African Association for Conflict Intervention (SAACI), University of Port Elizabeth, 25-28 November 1992.

Moses, Jacobus Johannes 1990. People's Courts and People's Justice: A Critical Review of the Current State of Knowledge of People's Courts, with a Particular Focus on South Africa. Master's Thesis, University of Cape Town.

Nathan, Laurie 1993. An Imperfect Bridge: Crossing to Democracy on the Peace Accord. Track Two 2 (2).

National Peace Accord 1991. Signed in South Africa 14 September 1991. Available at <http:// www.anc.org.za/ancdocs/history/transition/npaccord.html> Accessed Nov. 2008.

Nina, Daniel 1995. Community Courts in South Africa. Social Justice Resource Project, Institute of Criminology, University of Cape Town, May 1995.

Ntsebeza, Lungisile 2005. Democracy compromised: Chiefs and the politics of the land in South Africa. Boston, MA: Brill.

Rantete, Johannes 1998. The African National Congress and the Negotiated Settlement in South Africa. Pretoria: J.L. van Schaik.

Rothchild, Donald 1997. Managing Ethnic Conflict in Africa: Pressures and Incentives for Cooperation. Washington, D.C.: The Brookings Institution.

Schärf, Wilfried \& Daniel Nina 2001. The Other Law: Non-state Ordering in Contemporary South Africa. Cape Town: Juta. 


\section{Deji Olukotun}

Seekings, Jeremy 2001. Social ordering and control in the African townships of South Africa: an historical overview of extra-state initiatives from the 1940s to the 1990s. In: Schärf \& Nina 2001.

Shaer, M. \& Nossel, S. 1992. Groundswell at the Grassroots: the Challenge Posed by Peace Accord Dispute Resolution Committees. Paper presented at the Fifth Annual Conference of the South African Association for Conflict Intervention (SAACI), University of Port Elizabeth, 25-28 November 1992.

Shaw, Mark 1993. Crying Peace where there is None?: The Functioning and Future of Local Peace Committees of the National Peace Accord. Centre for Policy Studies Transition Series, Report No. 31, Aug. 1993. Johannesburg: Centre for Policy Studies

Siebert, Hannes 1994. Not the Last Word on Peace. Track Two 3 (2/3).

SALC (South African Law Commission) 2005. Commission Paper 686: Arbitration: Community Dispute Resolution Structures (Project 94), Draft Report. March 2005.

Spies, Chris 2002. South Africa's National Peace Accord: Its Structures and Functions. In: Barnes, Catherine (ed), Accord: An International Review of Peace Initiatives 13.

Stober, Paul 1995. Brought to Light. In: In the Name of Peace. Johannesburg: Sowetan.

Zehr, Howard \& Barb Towes (eds) 2004. Critical Issues in Restorative Justice. Monsey, New York: Criminal Justice Press. 